\title{
COXEN Score 40
}

National Cancer Institute

\section{Source}

National Cancer Institute. COXEN Score 40. NCI Thesaurus. Code C128237.

A score of 40 on the COXEN Sensitivity Scale. 